\title{
Development of Ti-Ag-Fe ternary titanium alloy for dental application
}

\author{
B.B. Zhang, ${ }^{1}$ B.L. Wang, ${ }^{1}$ Y.B. Wang, ${ }^{2}$ L. Li, ${ }^{1}$ Y.F. Zheng, ${ }^{1,2}$ Y. Liu $^{3}$ \\ ${ }^{1}$ Center for Biomedical Materials and Engineering, Harbin Engineering University, Harbin 150001, China \\ ${ }^{2}$ Department of Advanced Materials and Nanotechnology, College of Engineering, Peking University, Beijing 100871, China \\ ${ }^{3}$ School of Mechanical Engineering, The University of Western Australia, Crawley, WA 6009 Australia
}

Received 4 December 2010; revised 6 June 2011; accepted 25 June 2011

Published online 21 November 2011 in Wiley Online Library (wileyonlinelibrary.com). DOI: 10.1002/jbm.b.31937

\begin{abstract}
A series of titanium-silver-iron ternary alloys have been prepared in this study, and their feasibility as dental materials has been evaluated by the microstructural examination, mechanical testing, corrosion resistance evaluation, surface analysis, and cytotoxicity tests. More and more $\beta$-Ti phase appears at room temperature and retains with the increasing of $\mathrm{Fe}$ content in $\mathrm{Ti}-5 \mathrm{Ag}-\mathrm{xFe}$ alloy systems. The compression strength, wear resistance, and microhardness increase largely $(p<0.05)$ by the addition of element Fe to Ti-Ag alloy. Moreover, when comparing with commercial pure titanium ( $\mathrm{CP} \mathrm{Ti})$, nobler electrochemical corrosion behavior could be obtained for Ti-5Ag-1Fe and Ti-5Ag-2.5Fe alloys in the $1 \%$ lactic acid solution $(\mathrm{pH}=2.1)$ and $0.1 \mathrm{~mol} / \mathrm{L}$
\end{abstract}

$\mathrm{H}_{2} \mathrm{O}_{2}+0.9 \% \mathrm{NaCl}$ solution $(\mathrm{pH}=4.0)$. The released metal ions from $\mathrm{Ti}-5 \mathrm{Ag}-\mathrm{xFe}$ alloys into the simulated fluid are trace, similar to the case of $\mathrm{CP} \mathrm{Ti}$. The addition of $\mathrm{Fe}$ slightly decreases the corrosion resistance of Ti-5Ag alloy. All experimental Ti-5Ag-xFe alloy extracts do not present any cytotoxicity to L-929 and NIH3T3 cell lines. All in all, the combination of superior corrosion resistance and enhanced mechanical properties make $\mathrm{Ti}-5 \mathrm{Ag}-1 \mathrm{Fe}$ alloy and $\mathrm{Ti}-5 \mathrm{Ag}-2.5 \mathrm{Fe}$ alloy suitable for dental applications. (C) 2011 Wiley Periodicals, Inc. J Biomed Mater Res Part B: Appl Biomater 100B: 185-196, 2012.

Key Words: Ti-Ag-Fe alloys, mechanical properties, corrosion, ion release, cytotoxicity

How to cite this article: Zhang B.B., Wang B.L., Wang Y.B., Li L., Zheng Y.F., Liu Y. 2012. Development of Ti-Ag-Fe ternary titanium alloy for dental application. J Biomed Mater Res Part B 2012:100B:185-196.

\section{INTRODUCTION}

Commercial pure titanium (CP Ti) has been widely used as biomaterials due to its light weight, high corrosion resistance, and excellent biocompatibility. ${ }^{1,2}$ However, the insufficient strength and poor wear resistance of unalloyed titanium (Ti) was often complained. ${ }^{3,4}$ Because the properties of unalloyed titanium are not suitable for certain purposes, many titanium alloys, such as titanium-copper ${ }^{3,5-7}$ alloys, titanium-silver alloys, ${ }^{6-10}$ titanium-hafnium alloys, ${ }^{11,12}$ and titanium-zirconium alloys ${ }^{13}$ have been developed for dental application, and their properties have been studied mainly to improve the strength and castability of pure titanium.

Among these alloys, titanium-silver alloys are expected to be promising candidates for dental applications. ${ }^{6-10}$ The tensile strength and grindability of pure titanium could be improved by silver (Ag) addition. ${ }^{6,8}$ It was reported that the tensile strength of $\mathrm{Ti}-20 \mathrm{Ag}$ alloy is $60 \%$ higher than that of pure titanium; moreover, the elongation is over $19 \%{ }^{6}$ The grindability of titanium was also found to be improved by alloying with Ag element, especially at high speed grinding. ${ }^{7}$ The changes in the mechanical properties by alloying ele- ment Ag are considered to be caused by solid-solution strengthening of silver in titanium matrix and by precipitation hardening of the $\mathrm{Ti}_{2} \mathrm{Ag}$ intermetallic compound. ${ }^{6}$ In our previous work, ${ }^{10}$ the presence of $5 \mathrm{wt} \% \mathrm{Ag}$ is found to be enough to raise the corrosion potential of the Ti-Ag system, Ti-5Ag alloy exhibited good passivation behavior in simulated body environment. Moreover, Oh et al. ${ }^{8}$ reported that Ti-Ag alloys (0-4.5 at \%) exhibit little cytotoxicity to the mouse fibroblast cell line. However, the yield strength of Ti$5 \mathrm{Ag}$ alloy is about $280 \mathrm{MPa},{ }^{6}$ which is still much lower than that of Ti-6Al-4V alloy (about $800 \mathrm{MPa}$ ).

Iron $(\mathrm{Fe})$ is a component of several metalloproteins and plays a crucial role in vital biochemical activities, such as oxygen sensing and transport, electron transfer, and catalysis. As a $\beta$-stabilizer, Fe has been added into pure titanium and titanium alloys such as titanium-zirconium and titanium-chromium binary alloys and could improve the strength and wear resistance. ${ }^{14-16}$ Moreover, by alloying with $\mathrm{Fe}$, it is possible to lower the melting point and lessen the reactivity of titanium, thus facilitating the casting process of dental titanium alloys. Some alloys added with $\mathrm{Fe}$,

Correspondence to: Y.F. Zheng; e-mail: yfzheng@pku.edu.cn

Contract grant sponsor: National Basic Research Program of China (973 Program); contract grant number: $2012 \mathrm{CB} 619102$

Contract grant sponsor: Fundamental Research Funds for the Central Universities; contract grant numbers: HEUCF101013, HEUCFZ1017

Contract grant sponsor: National High Technology Research and Development Program of China (863 Program); contract grant numbers: 2011AA030101, 2011AA030103

Contract grant sponsor: Natural Science Foundation of Heilongjiang Province; contract grant number: ZD201012

Contract grant sponsor: National Natural Science Foundation of China; contract grant number: 51041004 
such as Ti-5Al-2.5Fe alloy, ${ }^{17}$ have been successfully used as biomedical materials. In the 1950s, the mechanical properties of Ti-Ag-Fe alloy were primarily investigated, and it was shown that the addition of Fe could greatly improve the tensile strength of Ti-Ag alloys. ${ }^{18}$ Yet, up to date, the information about the microstructure, corrosion resistance, surface film, dissolution behavior, and cytotoxicity of the Ti-Ag-Fe alloys is scarce.

In this study, Ti-Ag-Fe alloys with different Fe contents are systemically investigated by means of optical microscope, X-ray diffraction (XRD), compression tests, sliding wear tests, microhardness tests, XPS tests, electrochemical corrosion tests, immersion tests, and cytotoxicity tests, with the aim of developing new Ti-Ag-Fe alloy system as dental materials.

\section{MATERIALS AND METHODS}

\section{Sample preparation}

Ti-5Ag-xFe alloys $(x=0,1,2.5$, and 5 wt $\%)$ were prepared from grade zero titanium ( $99.9 \%$ in purity), silver wire (99.9\% in purity), and iron (99.9\% in purity) by means of arc melting in argon atmosphere. The button ingots with the weight of about $30 \mathrm{~g}$ were remelted four times for homogeneity. CP Ti (grade 2 ASTM-F0067-00 ${ }^{19}$ ) was used as reference. Specimens with different shapes were cut from the ingot and then mechanically polished step by step, with $400 \#, 1000 \#$, and 2000\# silicon carbide papers and finally cleaned with ultrasonic in acetone and alcohol for about $10 \mathrm{~min}$.

\section{Microstructure}

For optical microstructure test, specimens were mechanically polished, etched, and observed by optical microscope. Phase identification was carried out by XRD using Rigaku Dmax-2400 with the scan rate of $4^{\circ} / \mathrm{min}$.

\section{Mechanical property tests}

For dental devices such as dental implants, compressive stress was loaded frequently during chewing, rather than tensile laoding ${ }^{20}$; therefore, the compression test was used to evaluate the mechanical properties of Ti-5Ag-xFe alloys. The compression properties were tested using an Instron testing machine (Instron 3365, MA) at a strain rate of $1 \times$ $10^{-4} \mathrm{~s}^{-1}$ at room temperature in quintuplicate for each sample group. The cuboid compression samples with the aspect ratio of $2: 1(2.5 \mathrm{~mm} \times 2.5 \mathrm{~mm} \times 5 \mathrm{~mm})$ were prepared.

Sliding wear tests were performed on a reciprocal pinon-disc type wear device, similar to the procedure described in reference. ${ }^{21}$ The pin was made of $\mathrm{Si}_{3} \mathrm{~N}_{4}$, and specimens were used as disk. The pin and the disc were cleaned ultrasonically using acetone and ethanol. A normal load of $4 \mathrm{~N}$ was applied to the specimens. The disk was reciprocated at a velocity of $120 \mathrm{rpm}$. The wear characteristics were evaluated by the volume loss of the specimens after sliding for $30 \mathrm{~min}$. All the wear-resistance measurements were carried out in quintuplicate. The microhardness of specimens was measured at $200 \mathrm{~g}$ for $30 \mathrm{~s}$. The microhardness tests were repeated five times on five different specimens to obtain reliable results.

\section{X-ray photoelectron spectroscopy}

The XPS data were taken on an AXIS-Ultra instrument from Kratos Analytical using monochromatic $\mathrm{Al} \mathrm{K} \alpha$ radiation (225 W, $15 \mathrm{~mA}$, and $15 \mathrm{kV}$ ) and low-energy electron flooding for charge compensation. The depth from which information can be derived is a few nanometers. ${ }^{22}$ To compensate for surface charges effects, the binding energies were calibrated using C 1s hydrocarbon peak at $284.80 \mathrm{eV}$.

\section{Corrosion behavior tests}

The cell used was conventional three-electrode configuration with a Pt electrode and a saturated calomel electrode (SCE) as the counter electrode and reference electrode, respectively. All the measurements were carried out on an electro-chemical workstation (CHI660C, China). The electrolyte was $1 \%$ lactic acid solution (the $\mathrm{pH}$ is about 2.1) and $0.1 \mathrm{~mol} / \mathrm{L}_{2} \mathrm{O}_{2}+0.9 \% \mathrm{NaCl}$ solution ( $\mathrm{pH} 4.0$ adjusted by lactic acid to accelerate the corrosion rate), made up with laboratory grade chemicals and deionized water. Lactic acid could be formed in dental plaques, ${ }^{23}$ and $\mathrm{H}_{2} \mathrm{O}_{2}$ is likely to be generated in the body in case of inflammation in the surrounding of implant or present in mouth washes. ${ }^{24}$

In the open circuit potential tests, the specimens were submerged into the electrolyte without any imposed potential for $7200 \mathrm{~s}$. The potentiodynamic polarization curves of the test samples were measured from $-600 \mathrm{mV}$ to $2500 \mathrm{mV}$ (vs. SCE) with a scan rate of $1 \mathrm{mV} / \mathrm{s}$. The testing was repeated five times on individual samples at the same group to obtain reliable results.

The variations of the corrosion behavior for the passive film formed on the surface of the samples were studied using the electrochemical impedance spectroscopy (EIS) technique. The impedance spectra were acquired in the frequency range of $10^{4}-10^{-2} \mathrm{~Hz}$ with a $10 \mathrm{mV}$ amplitude sine wave at open circuit potential. The EIS tests were carried out in quintuplicate to obtain reliable results. A $R_{\mathrm{S}}\left(Q_{1} R_{1}\right)$ model $^{25}$ is used as the equivalent circuit model to fit the EIS data in the case of single passive film presented on the metal surface. $R_{\mathrm{S}}$ is the solution resistance, $R_{1}$ is the passive film resistance, and $Q_{1}$ is the constant-phase element (CPE) for the passive film. $Q$ and $n$ are the magnitude and the exponent of the CPE, respectively.

\section{Dissolution tests}

About 1\% lactic solution and $0.1 \mathrm{~mol} / \mathrm{L} \mathrm{H}_{2} \mathrm{O}_{2}+0.9 \% \mathrm{NaCl}$ solution, which were usually used as corrosive solutions in dissolution tests, ${ }^{26,27}$ were prepared for the dissolution tests. Specimens were cut into the size of $10 \mathrm{~mm} \times 10 \mathrm{~mm}$ $\times 1 \mathrm{~mm}$. Each specimen was placed in a polyethylene bottle and then $7 \mathrm{~mL}$ test solution was added. The bottles were incubated at $37^{\circ} \mathrm{C}$ for $168 \mathrm{~h}$. The inductively coupled plasma atomic emission spectrometry (Leeman, Profile ICPAES) was used to measure the concentrations of titanium and alloying element ions, which had dissolved from the 
experimental alloy plates. An average of five measurements was taken for each group.

\section{Cytotoxicity tests}

Murine fibroblast cells (L-929 and NIH3T3) were selected to evaluate the cytotoxicity of Ti-5Ag-xFe alloys, and they were cultured in Dulbecco's modified Eagle's medium (DMEM), 10\% fetal bovine serum, $100 \mu \mathrm{g} \mathrm{ml}{ }^{-1}$ penicillin, and $100 \mu \mathrm{g} \mathrm{ml}^{-1}$ streptomycin at $37^{\circ} \mathrm{C}$ under humidified atmosphere of $5 \% \mathrm{CO}_{2}$. The cytotoxicity tests were carried out by indirect contact. Extracts were prepared using DMEM serum-free medium as the extraction medium with the surface area of extraction medium ratio $1 \mathrm{~mL} / 3 \mathrm{~cm}^{2}$ in a humidified atmosphere with $5 \% \mathrm{CO}_{2}$ at $37^{\circ} \mathrm{C}$ for $72 \mathrm{~h}$. The control groups involved the use of DMEM medium as negative control and 10\% DMSO in DMEM medium as positive control. Cells were incubated in 96-well cell culture plates at $5 \times 10^{3}$ cells $/ 100 \mu \mathrm{L}$ medium in each well and incubated for $24 \mathrm{~h}$ to allow attachment. For each sample group, the extract was tested in five wells; the cytotoxicity tests were repeated three times to obtain reliable results. The medium was then replaced with $100 \mu \mathrm{L}$ of different experimental extracts. After incubating the cells in a humidified atmosphere with $5 \% \mathrm{CO}_{2}$ at $37^{\circ} \mathrm{C}$ for 2,4 , and 7 days, $10 \mu \mathrm{L}$ MTT was added to each well. The samples were further incubated with MTT for $4 \mathrm{~h}$ at $37^{\circ} \mathrm{C}$, and then $100 \mu \mathrm{L}$ formazan solubilization solution $(10 \%$ SDS in $0.01 M \mathrm{HCl})$ was added in each well overnight in the incubator under humidified atmosphere. The spectrophotometrical absorbance of the samples was measured by microplate reader (Bio-RAD680) at $570 \mathrm{~nm}$ with a reference wavelength of $630 \mathrm{~nm}$.

\section{Statistical analysis}

Statistical procedures were performed with SPSS 16.0. The significance of the obtained data was performed using oneway analysis of variance, followed by Tukey's test for multiple comparison procedure with a confidence level of $95 \%$ $(p<0.05)$ considered statistically significance.

\section{RESULTS}

\section{Microstructure and phase identification}

The XRD patterns of CP Ti and various Ti-5Ag-xFe alloys are shown in Figure 1. The crystal structure of Ti-5Ag-xFe alloys is sensitive to their Fe content. It can be seen that $\mathrm{CP} \mathrm{Ti}$, Ti$5 \mathrm{Ag}$, and Ti-5Ag-1Fe alloys contained a single $\alpha$-Ti phase at room temperature, whereas the $\beta$-Ti phase peaks show up obviously besides the residual $\alpha$-Ti phase when Fe content is over $2.5 \%$. For Ti-5Ag-5Fe alloy, the appearance of $\alpha$-Ti phase at room temperature is significantly suppressed, and the meta-stabilized high-temperature phase, $\beta$-Ti phase, is dominantly retained. For Ti-5Ag-xFe alloy system, $\mathrm{Fe}$ is believed to be an attractive $\beta$ phase stabilizer, the $\beta$ phase can be retained when Fe content is higher than 5 wt \%. This is in coincidence with the studies on the Ti-Fe binary alloys carried out by Dobromyslov et al. ${ }^{28}$

The optical micrographs of $\mathrm{CP} \mathrm{Ti}$ and Ti-5Ag-xFe alloys are shown in Figure 2. Columnar crystals could be seen for

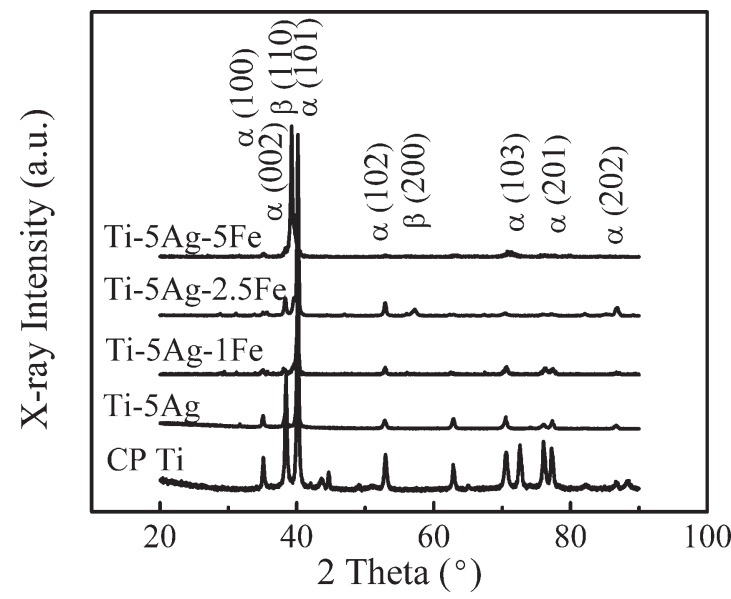

FIGURE 1. XRD patterns of $\mathrm{CP} \mathrm{Ti}$ and various $\mathrm{Ti}-5 \mathrm{Ag}-\mathrm{xFe}$ alloys.

CP Ti, as shown in Figure 2(a). Ti-5Ag alloy exhibits typical cast dendritic microstructure. It can be seen from Figure 2 (c) that the $\alpha$-Ti phase formed in Ti-5Ag-1Fe alloy shows lamellar structure, whereas Ti-5Ag-2.5Fe alloy exhibits typical $(\alpha+\beta)$ biphasic pattern. At 5\% Fe composition point, $\beta$ Ti phase with granular equiaxed structure is mainly retained in the microstructure of Ti-5Ag-xFe alloy.

\section{Mechanical properties}

The microhardness values of $\mathrm{CP} \mathrm{Ti}, \mathrm{Ti}-5 \mathrm{Ag}$ alloy, and Ti$5 \mathrm{Ag}-\mathrm{xFe}$ alloys are shown in Figure 3. CP Ti exhibits a relative low microhardenss $(\sim 190 \mathrm{HV})$, which is similar to the results reported. ${ }^{29}$ Ti-5Ag binary alloy has a significantly higher $(p<0.05)$ microhardness $(206 \pm 4 \mathrm{HV})$ compared to $\mathrm{CP}$ Ti $(189 \pm 10 \mathrm{HV})$. Ti-5Ag-2.5Fe alloy exhibits the largest microhardness (about $494 \pm 5 \mathrm{HV}$ ), which is even higher than that of Co-Cr alloy (350-390 HV) ${ }^{30}$ and Ti-6Al$4 \mathrm{~V}$ alloy $(\sim 380 \mathrm{HV}) .{ }^{31}$ The hardness of Ti-5Ag-xFe alloys increases largely with the increasing of Fe content when Fe content is no more than $2.5 \%$. It tends to rise with increased Fe contents because of solid-solution strengthening mechanism. In the cases of alloy with $5 \% \mathrm{Fe}$, the microhardness decreases to $303 \pm 5 \mathrm{HV}$.

The room temperature uniaxial compressive stressstrain curves for the Ti-5Ag-xFe alloys are shown in Figure 4. CP Ti, Ti-5Ag, and Ti-5Ag-1Fe alloys exhibit large plastic deformation without fracture during the testing, whereas Ti$5 \mathrm{Ag}-5 \mathrm{Fe}$ alloy fails in a brittle manner with a maximum strength of about $1248 \pm 92 \mathrm{MPa}$.

One of the disadvantages of titanium for structural applications is its poor tribological characteristics. ${ }^{32}$ Insufficient wear resistance can bring about occlusion disharmony and the masticatory lowering. ${ }^{33}$ Figure 5 shows the volume losses of $\mathrm{CP} \mathrm{Ti}$, Ti-5Ag alloy, and Ti-5Ag-xFe alloys after wear tests. The volume losses of the Ti-5Ag-xFe alloys (lower than $0.63 \mathrm{~mm}^{3}$ ) are significantly lower than that of the CP Ti $\left(1.28 \pm 0.12 \mathrm{~mm}^{3}, p<0.05\right)$ and the Ti-5Ag alloy (1.29 $\left.\pm 0.12 \mathrm{~mm}^{3}, p<0.05\right)$. Among all Ti-5Ag-xFe alloys, Ti-5Ag-2.5Fe alloy exhibits the lowest volume loss $(0.38 \pm$ $0.13 \mathrm{~mm}^{3}$ ), indicating the best wear resistance. 

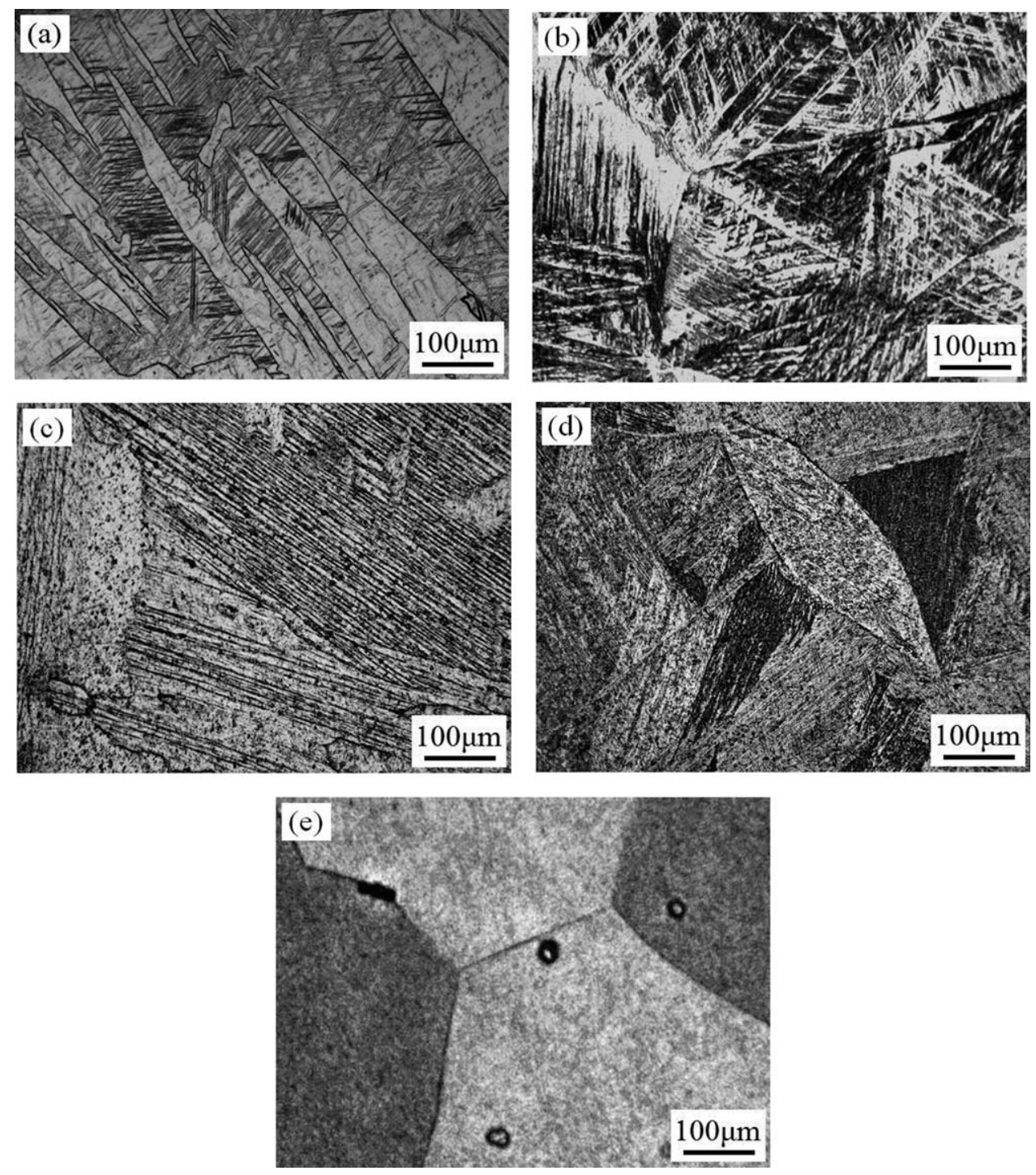

FIGURE 2. Optical micrograph of CP Ti and various Ti-5Ag-xFe alloys: (a) CP Ti, (b) Ti-5Ag alloy, (c) Ti-5Ag-1Fe alloy, (d) Ti-5Ag-2.5Fe alloy, and (e) Ti-5Ag-5Fe alloy.

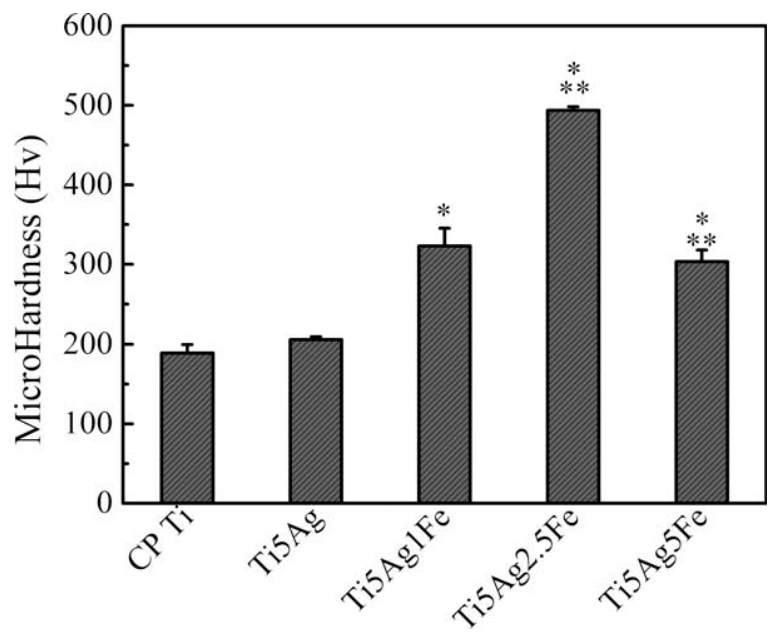

FIGURE 3. Microhardness of $\mathrm{CP} \mathrm{Ti}$ and various $\mathrm{Ti}-5 \mathrm{Ag}-\mathrm{xFe}$ alloys. * indicates $p<0.05$ when comparing with Ti-5Ag group. ${ }^{* *}$ indicates $p<0.05$ when comparing with Ti-5Ag-1Fe group.

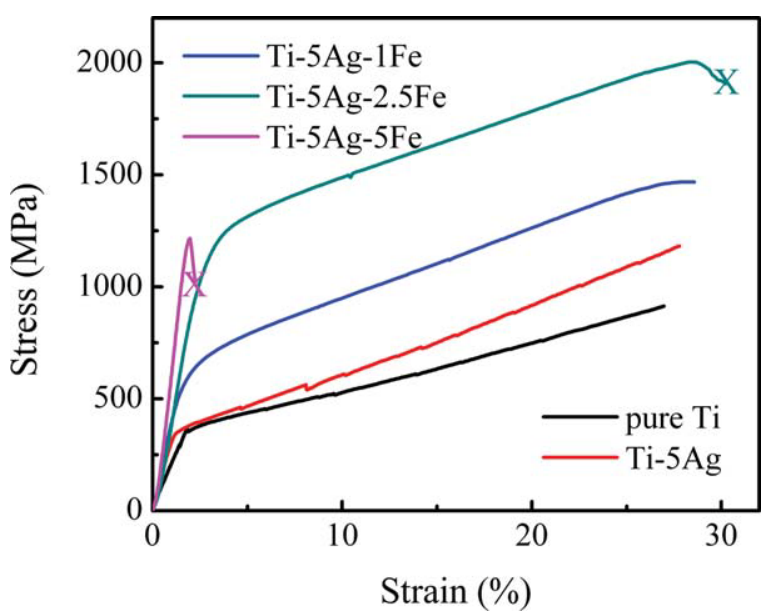

FIGURE 4. Room temperature compressive stress-strain curves for CP $\mathrm{Ti}$ and various $\mathrm{Ti}-5 \mathrm{Ag}-\mathrm{xFe}$ alloys, in which " $X$ " represents fracture position. [Color figure can be viewed in the online issue, which is available at wileyonlinelibrary.com.] 


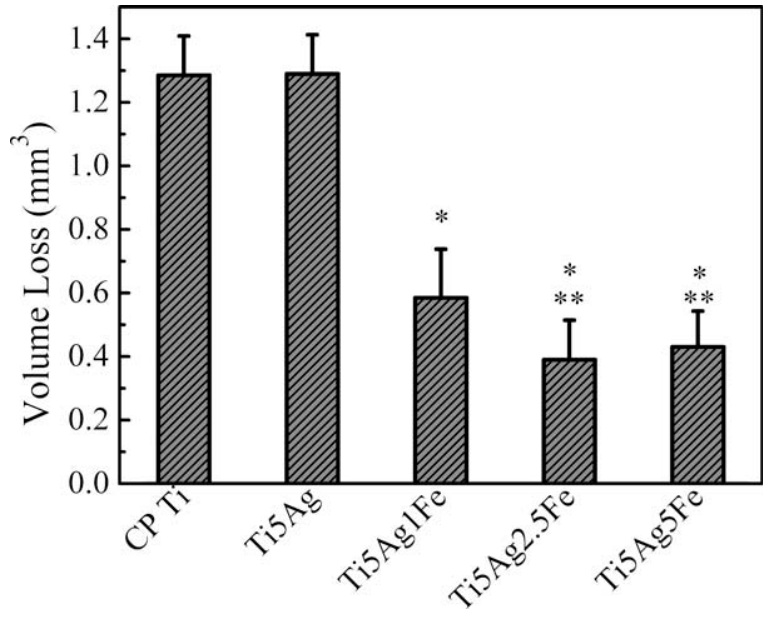

FIGURE 5. Volume losses of $\mathrm{CP} \mathrm{Ti}$ and various $\mathrm{Ti}-5 \mathrm{Ag}-\mathrm{xFe}$ alloys in wear tests. ${ }^{*}$ indicates $p<0.05$ when comparing with Ti-5Ag group. ** indicates $p<0.05$ when comparing with $\mathrm{Ti}-5 \mathrm{Ag}-1 \mathrm{Fe}$ group.
The SEM images of worn surfaces of the specimens are shown in Figure 6. For $\mathrm{CP} \mathrm{Ti}$, some pieces peeling off the contact area have been worn by the load and friction and turn to wear particles as a result of sliding. These features suggest that the wear mechanism is mainly microcutting. The worn surface of Ti-5Ag-1Fe alloy shows typical sliding wear characteristic, and deep parallel scars could be observed. In comparison, Ti-5Ag-2.5Fe alloy and Ti-5Ag-5Fe alloy reveal much smoother worn surfaces, no severe fracture happened on the surfaces, which accounts for the longer wear life.

These SEM observations are consistent with the conclusions derived from the hardness values and volume losses presented above. It could be concluded that Ti-5Ag-xFe alloys exhibit much higher wear resistance when compared with CP Ti.

\section{Surface analyses}

The XPS survey spectra obtained from mechanically polished CP Ti, Ti-5Ag alloy, and Ti-5Ag-5Fe alloy are shown in
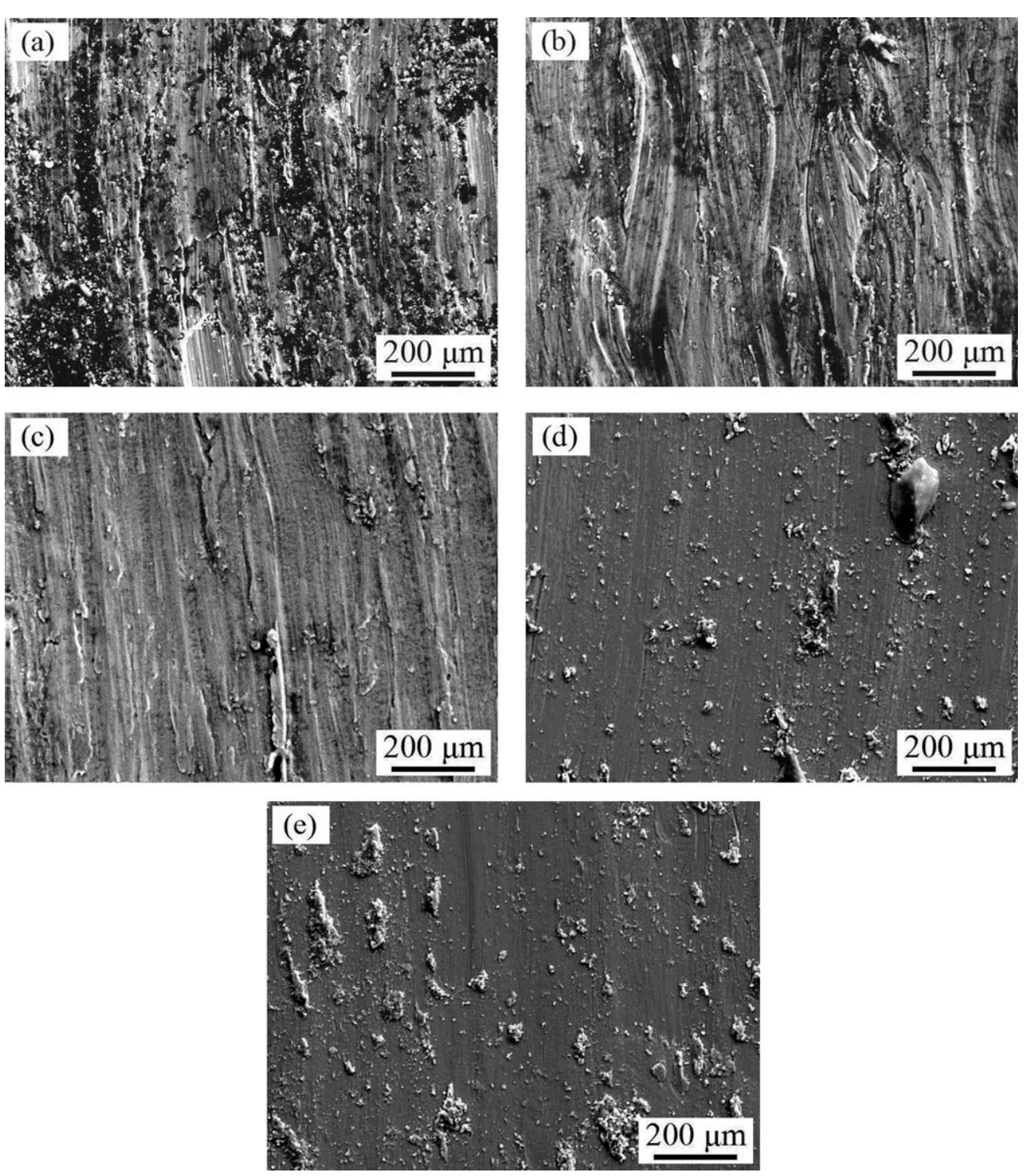

FIGURE 6. Worn surfaces of (a) CP Ti, (b) Ti-5Ag alloy, (c) Ti-5Ag-1Fe alloy, (d) Ti-5Ag-2.5Fe alloy, and (e) Ti-5Ag-5Fe alloy. 


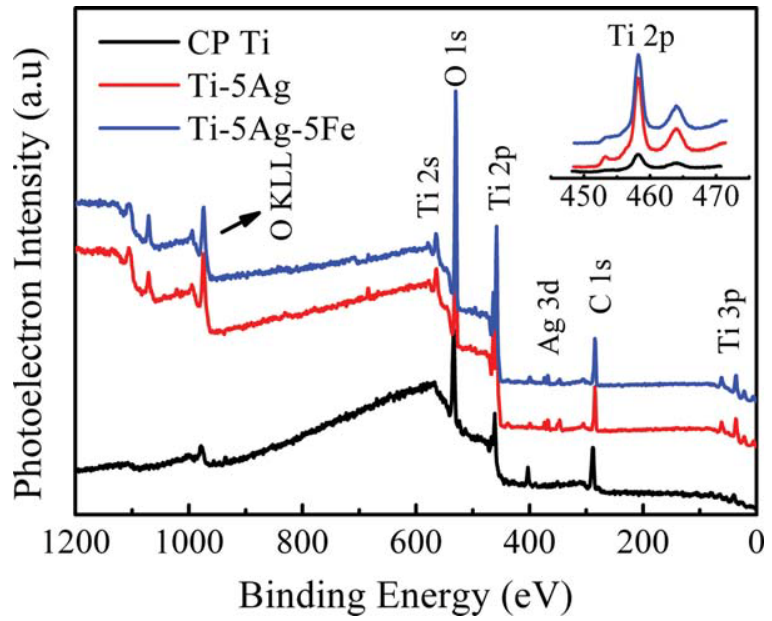

FIGURE 7. XPS surface chemical analyses of CP Ti, Ti-5Ag alloy, and Ti-5Ag-5Fe alloy. [Color figure can be viewed in the online issue, which is available at wileyonlinelibrary.com.]

Figure 7. Apart from carbon, titanium, silver, and oxygen are detected from Ti-5Ag alloy. It is evident that the surface of CP Ti, Ti-5Ag alloy, and Ti-5Ag-5Fe alloy samples mainly consisted of $\mathrm{TiO}_{2}$. Small iron peak which indicated the presence of iron could be observed in the XPS survey spectrum of Ti-5Ag-5Fe alloy. The insets show enlarged images of the sections of the spectra for $\mathrm{Ti}$ at about $460 \mathrm{eV}$, which indicate that the binding energy spectrum for $\mathrm{Ti}$ in $\mathrm{CP} \mathrm{Ti}, \mathrm{Ti}-5 \mathrm{Ag}$ alloy, and Ti-5Ag-5Fe alloy is almost the same. In other words, the passive films on the surface of $\mathrm{CP} \mathrm{Ti}$, Ti-5Ag alloy, and Ti-5Ag-5Fe alloy have similar structure.

\section{Corrosion behavior}

Figure $8(a, b)$ presents the typical open-circuit potential curves of $\mathrm{CP} \mathrm{Ti}, \mathrm{Ti}-5 \mathrm{Ag}$ alloy, and Ti-5Ag-xFe alloys as a function of immersion time in the two solutions. In lactic acid solution, for all experimental alloys, the shapes of the open-circuit potential curves trend forward with greater number of noble potentials. This phenomenon indicates the thickening of the passive oxide film. After $7200 \mathrm{~s}$ immersion, the corrosion potential of Ti-5Ag-2.5Fe alloy is $-18 \pm$ $7 \mathrm{mV}$, which is significantly higher $(p<0.05)$ than that of CP Ti $(-70 \pm 24 \mathrm{mV})$, Ti-5Ag alloy $(-79 \pm 44 \mathrm{mV})$, Ti$5 \mathrm{Ag}-1 \mathrm{Fe}(-59 \pm 31 \mathrm{mV})$, and Ti-5Ag-5Fe alloy $(-72 \pm 3$ $\mathrm{mV}$ ). There is no significant difference among $\mathrm{CP} \mathrm{Ti}, \mathrm{Ti}-5 \mathrm{Ag}$ alloy, and Ti-5Ag-5Fe alloy ( $p>0.05$ ). In $\mathrm{H}_{2} \mathrm{O}_{2}$-contained solution, all alloys exhibit relative high corrosion potential (higher than $-100 \mathrm{mV}$ vs. SCE) at the beginning of the immersion. After $7200 \mathrm{~s}$ immersion, the corrosion potentials of Ti-5Ag, Ti-5Ag-1Fe, Ti-5Ag-2.5Fe, and Ti-5Ag-5Fe alloys are $-39 \pm 14 \mathrm{mV},-52 \pm 33 \mathrm{mV},-55 \pm 18 \mathrm{mV}$, and $69 \pm$ $22 \mathrm{mV}$, which are significantly higher $(p<0.05)$ than that of CP Ti $(-121 \pm 39 \mathrm{mV})$. Similar results can be observed in Ti-Ag binary alloys ${ }^{8-10}$ and Ti-Ag-Cu ternary alloys, ${ }^{34}$ and it assumed thicker or more stable oxide films formed on TiAg based alloys.

Figure 9 shows the typical potentiodynamic polarization plots for experimental alloys in different solutions. All the experimental samples exhibit similar potentiodynamic polarization patterns and current densities, and no breakdown potential could be observed at potentials below $1500 \mathrm{mV}$, which indicates that these passive films on the surface of experimental alloys are very integral and protective, thus preventing corrosion. ${ }^{35}$ Moreover, the passive behavior with identical values of current density can be observed, indicating that the corrosion mechanism of Ti-Ag-xFe alloys is similar to that of $\mathrm{CP} \mathrm{Ti}$. In lactic solution, the current density starts to increase at $\sim 1200 \mathrm{mV}$ (SCE) and then stabilizes again at a current density of about $10^{-5} \mathrm{~A} / \mathrm{cm}^{2}$. These results suggest that the passive film broke down in the same as that occurred during pitting nucleation and repassivation. ${ }^{36}$ In $\mathrm{H}_{2} \mathrm{O}_{2}$-contained solution, all experimental alloys present the same electrochemical feature. The anodic polarization curves show no active-passive transition, which is typical of a spontaneous passive behavior and agrees with the results of OCP measurements. The anodic current densities for $\mathrm{CP} \mathrm{Ti}$ and $\mathrm{Ti}-5 \mathrm{Ag}-\mathrm{xFe}$ alloys moderately increase with the increment of the potential [from $1.6 \pm 0.8 \times 10^{-5}$ $\mathrm{A} / \mathrm{cm}^{2}(500 \mathrm{mV}, \quad \mathrm{SCE})$ to $4.7 \pm 1.2 \times 10^{-5} \mathrm{~A} / \mathrm{cm}^{2}$ (1500 mV, SCE), $p<0.05)]$. No breakdown of the oxide films occurs up to $2500 \mathrm{mV} / \mathrm{SCE}$.
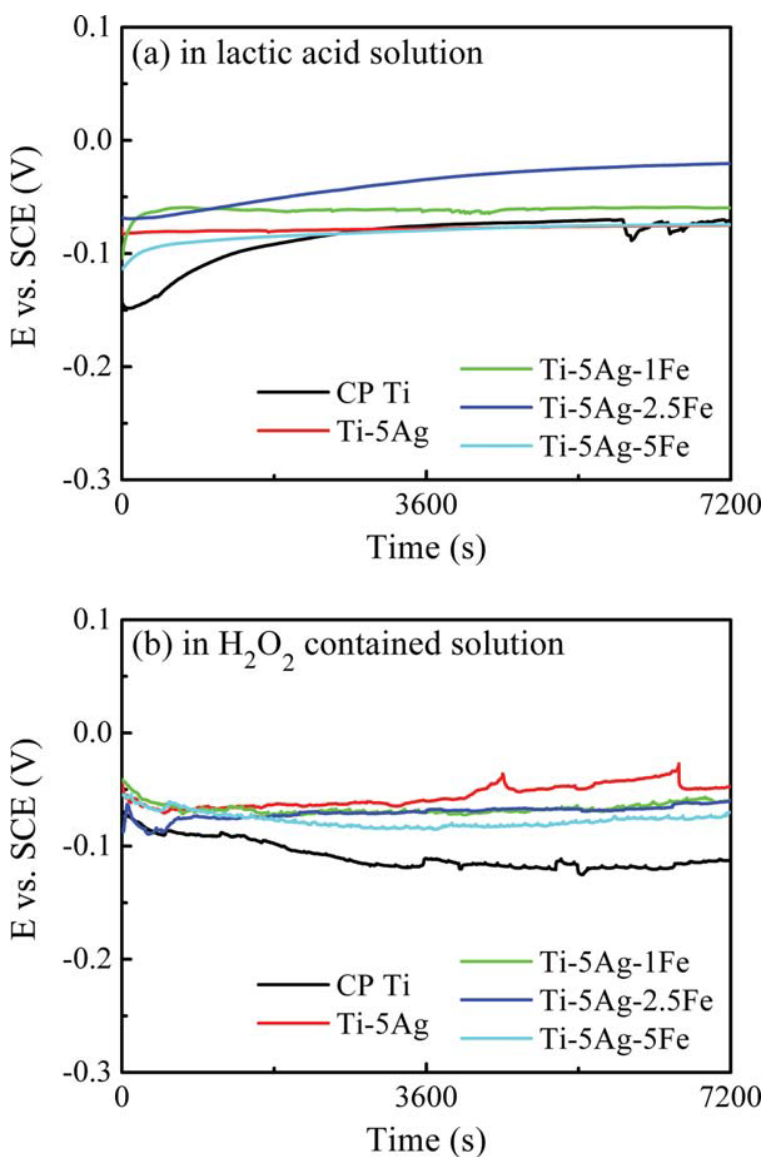

FIGURE 8. Open circuit potential curves of $\mathrm{CP} \mathrm{Ti}$ and various $\mathrm{Ti}-5 \mathrm{Ag}$ xFe alloys in $1 \%$ lactic acid solution (a) and $\mathrm{H}_{2} \mathrm{O}_{2}$ solution (b). [Color figure can be viewed in the online issue, which is available at wileyonlinelibrary.com.] 

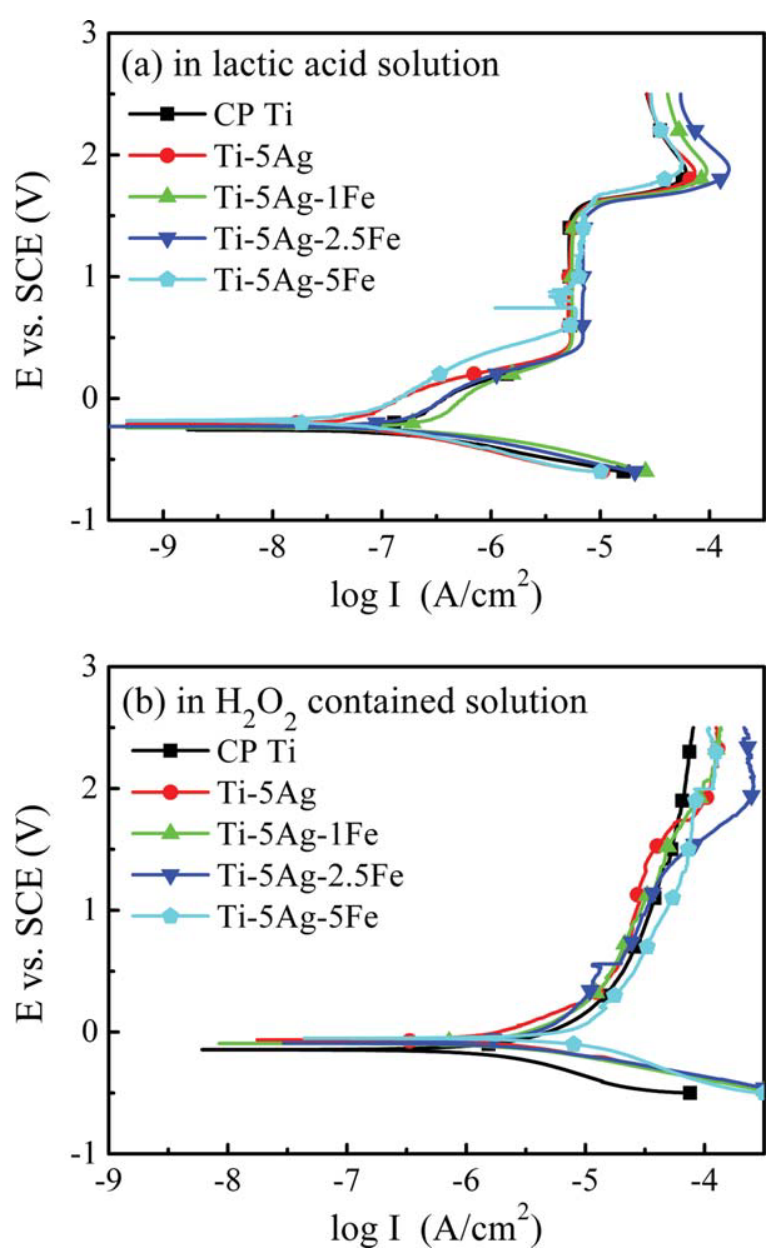

FIGURE 9. Potentiodynamic polarization curves of $\mathrm{CP} \mathrm{Ti}$ and various Ti-5Ag-xFe alloys in $1 \%$ lactic acid solution (a) and $\mathrm{H}_{2} \mathrm{O}_{2}$ solution (b). [Color figure can be viewed in the online issue, which is available at wileyonlinelibrary.com.]

To further characterize the surface passive formed in the testing solutions, the electrochemical impedance spectrum technique is used. The impedance spectra are presented as bode plots, as shown in Figure 10. The EIS patterns of all the experimental alloys are nearly identical. A highly capacitive behavior, typical of passive materials, is indicated from medium to low frequencies by phase angles approaching $90^{\circ}$, suggesting that a highly stable film is formed on tested alloy in the electrolyte used. ${ }^{37}$ This is consistent with the very low corrosion densities determined in polarization tests. Moreover, the intermediate frequency region $\left(10^{3}-10 \mathrm{~Hz}\right)$ has the maximum phase angle and the $\log |Z|$ versus $\log f$ slope approaching -1 . Those impedance responses correspond to the capacitive behavior of the electrode and describe the dielectric properties of the electronically conducting surface film. ${ }^{38} R_{\mathrm{s}}\left(Q_{1} R_{1}\right)$ model, as shown in Figure 11(a), is used as the equivalent circuit model to fit the EIS data. The fitted bode spectra and the electrochemical parameters obtained are listed in Figure 11(b) and Table I, respectively.

\section{Ion release behavior}

For dental alloys, systemic and local toxicity allergy, and carcinogenicity resulted from ions being released into the mouth. ${ }^{39}$ Various studies have reported that the release of harmful ions from dental alloys might cause certain longterm health problems. The amounts of dissolved metals from Ti-5Ag-xFe alloys in the two solutions are shown in Figure 12. It can be seen that Ti-5Ag-xFe alloys do not release elements $\mathrm{Ti}, \mathrm{Ag}$, and $\mathrm{Fe}$ in proportion to its composition. In $1 \%$ lactic acid solution, the dissolved titanium ion from all experimental alloys is at the same level. Trace silver ion released from Ti-5Ag-xFe alloys is detected. The quantity of $\mathrm{Fe}$ released gradually increases with an increase in Fe content.

In $\mathrm{H}_{2} \mathrm{O}_{2}$-contained solution, $\mathrm{CP} \mathrm{Ti}$ shows the highest level of dissolution, and the amount of dissolved titanium is about $2 \mu \mathrm{g} / \mathrm{cm}^{2}$. The amounts of dissolved titanium ion show a significant decrease $(p<0.05)$ for Ti-5Ag-xFe alloys. Although the largest concentration of $\mathrm{Ag}$ is only $5 \%$ in $\mathrm{Ti}-$ $5 \mathrm{Ag}$-xFe alloys, the quantity of element $\mathrm{Ag}$ released into the solution is somewhat higher than that of element Ti $(p<$ 0.05 for Ti-5Ag-1Fe, Ti-5Ag-2.5Fe, and Ti-5Ag-5Fe alloys). The total amounts of dissolved metal in $\mathrm{H}_{2} \mathrm{O}_{2}$-contained solution were relatively lower than that in $1 \%$ lactic solution, suggesting that $\mathrm{H}_{2} \mathrm{O}_{2}$-contained solution was not as corrosive as $1 \%$ lactic solution.

\section{In vitro cytotoxicity}

Figure 13 shows the viability of murine fibroblast cells L929 [Figure 13(a)] and NIH3T3 [Figure 13(b)] co-cultured
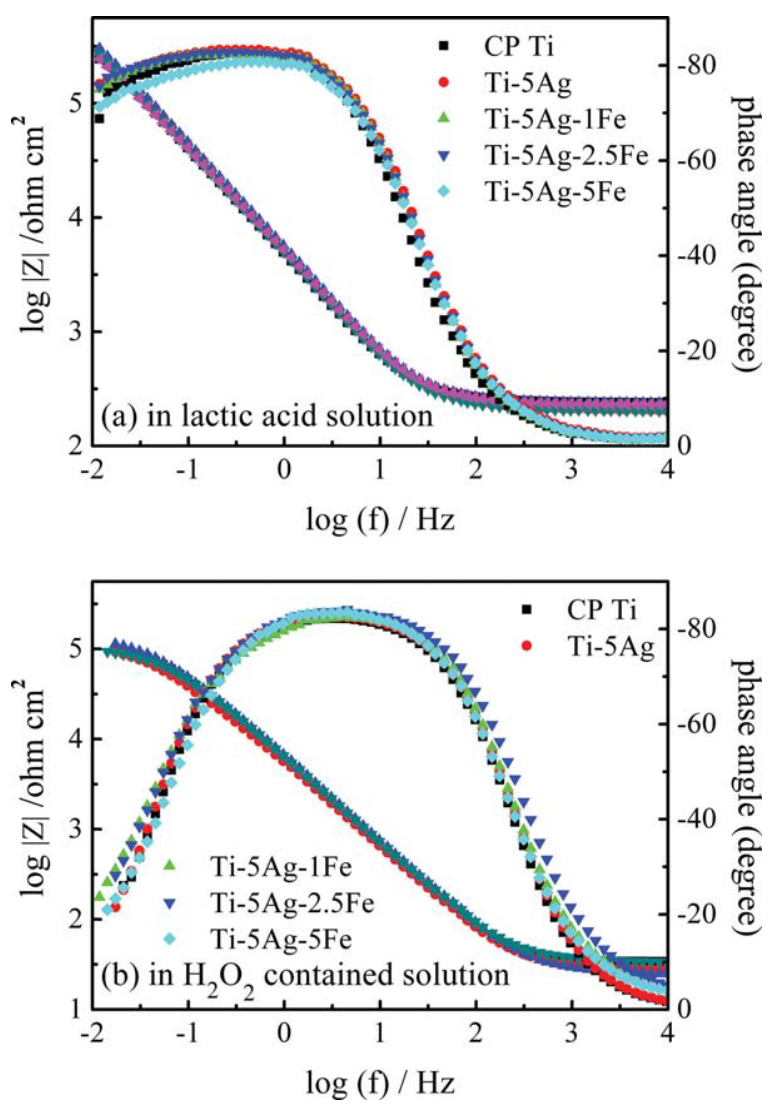

FIGURE 10. Electrochemical impedance spectra of $\mathrm{CP} \mathrm{Ti}$ and $\mathrm{Ti}-5 \mathrm{Ag}$ xFe alloys immersed in $1 \%$ lactic acid solution (a) and $\mathrm{H}_{2} \mathrm{O}_{2}$-contained solution (b). [Color figure can be viewed in the online issue, which is available at wileyonlinelibrary.com.] 

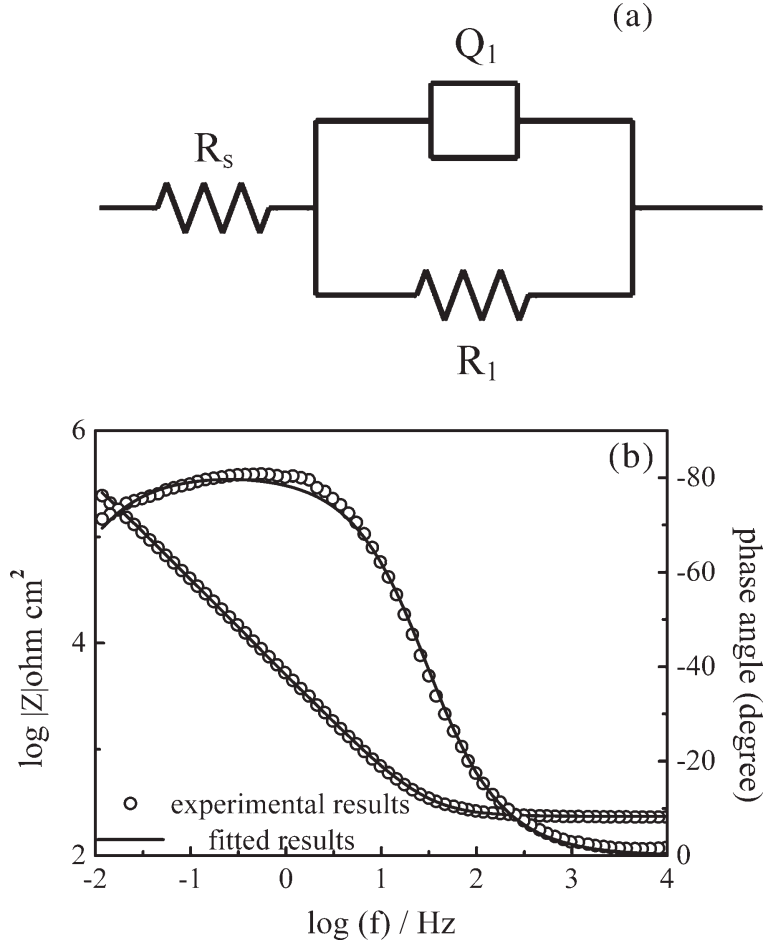

FIGURE 11. Equivalent circuit fitted for Ti-5Ag-xFe alloys (a) and fitted bode spectra of Ti-5Ag-5Fe alloy immersed in lactic acid solution (b).

with the extract of the experimental alloys and expressed as a percentage of the viability of cells cultured in negative control. It can be seen that both L-929 and NIH3T3 cells cultured in CP Ti and Ti-5Ag-xFe alloys extracts show similar cell viability to the negative control. For L-929 fibroblasts, after long time ( 2 and 4 days) culture, Ti-5Ag-xFe alloy groups exhibit almost the same cell viability in comparison with CP Ti group. In the case of NIH3T3 fibroblast cells, the viability of cells cultured in Ti-5Ag-xFe alloy extracts slightly decrease compared to that cultured in $\mathrm{CP}$ Ti for 1 day. The CP Ti and Ti-5Ag-xFe alloy groups show a little higher cell viabilities compared to that of the negative control group after 2 days culture.

\section{DISCUSSION}

The success of prefect dental materials depends on a myriad of factors ranging from the physical, chemical, and biological properties of the materials to the shape and structure of the production. In the case of dental titanium alloys, some of their important properties can be summarized as follows: (1) good mechanical properties, such as high strength, wear resistance, and hardness; dental materials should have excellent mechanical properties to provide sufficient force such as biting force. (2) high corrosion resistance; the human mouth presents a very aggressive fluid environment for dental materials no matter temporarily or permanently used. To minimize biologic risks, dental titanium alloys should have the best corrosion resistance and the lowest ion release of metal elements. (3) Excellent biocompatibility both in vitro and in vivo; dental materials are expected to be highly nontoxic and should not cause any inflammatory or allergic reactions to the surrounding tissues.

\section{Mechanical properties}

The mechanical properties of materials will influence their selection for use in dentistry. Different titanium alloys with various mechanical properties have been developed to meet the demands of various dental applications such as crowns, short-span bridges, thin crowns, and partial dentures. Figure 14 compares the strength and elongation of $\mathrm{Ti}-5 \mathrm{Ag}-2.5 \mathrm{Fe}$ alloy with some clinically used dental alloys ${ }^{19,40-47}$ and some newly developed cast titanium alloys., ${ }^{5,648-50}$ For all binary titanium alloys except Ti-Mo alloy, the elongation decreases with the increase in yield strength. These changes in strength and ductility occur mainly because of the solid solution strengthening and precipitation hardening. Compared to conventional dental materials, the yield strength of Ti-5Ag-2.5Fe alloy was several times high as that of CP Ti and human dentin; moreover, the elongation remained at a high level (>30\%). Compared to Ti-6Al-4V alloy, Ti-5Ag$2.5 \mathrm{Fe}$ alloy exhibited higher compressive yield strength and similar elongation. Ti-5Ag-2.5Fe alloy had excellent yield strength and proper elongation because of the combination of solid-solution strengthening by $\mathrm{Ag}$ and Fe and its $\alpha+\beta$ biphasic microstructure.

TABLE I. Electrochemical Impedance Parameters of CP Ti and Ti-5Ag-xFe Alloys in Lactic Acid Solution and $\mathrm{H}_{2} \mathrm{O}_{2}$-contained solution

\begin{tabular}{lccccc}
\hline Solution & Materials & $R_{\mathrm{s}}\left(\Omega \mathrm{cm}^{2}\right)$ & $Q_{1}\left(\mu \mathrm{F} / \mathrm{cm}^{2}\right)$ & $n$ & $R_{1}\left(\mathrm{M} \Omega \mathrm{cm}^{2}\right)$ \\
\hline Lactic acid & $\mathrm{CP} \mathrm{Ti}$ & $245.8 \pm 12.1$ & $38.8 \pm 9.2$ & $0.93 \pm 0.1$ & $1.15 \pm 0.43$ \\
solution & $\mathrm{Ti}-5 \mathrm{Ag}$ & $211.4 \pm 10.2$ & $24.3 \pm 7.7^{\mathrm{a}}$ & $0.93 \pm 0.2$ & $2.23 \pm 0.79^{\mathrm{a}}$ \\
& $\mathrm{Ti}-5 \mathrm{Ag}-1 \mathrm{Fe}$ & $241.3 \pm 4.8$ & $34.8 \pm 10.6^{\mathrm{a}}$ & $0.92 \pm 0.1$ & $2.14 \pm 0.49^{\mathrm{a}}$ \\
& $\mathrm{Ti}-5 \mathrm{Ag}-2.5 \mathrm{Fe}$ & $222.1 \pm 31.2$ & $38.9 \pm 4.1$ & $0.92 \pm 0.1$ & $2.28 \pm 0.26^{\mathrm{a}}$ \\
& $\mathrm{Ti}-5 \mathrm{Ag}-5 \mathrm{Fe}$ & $233.6 \pm 22.0$ & $37.4 \pm 7.2$ & $0.91 \pm 0.1$ & $1.25 \pm 0.26^{\mathrm{a}}$ \\
$\mathrm{H}_{2} \mathrm{O}_{2}$-contained & $\mathrm{CP} \mathrm{Ti}$ & $36.5 \pm 12.3$ & $30.9 \pm 4.5$ & $0.94 \pm 0.2$ & $1.01 \pm 0.08$ \\
solution & $\mathrm{Ti}-5 \mathrm{Ag}$ & $34.0 \pm 19.8$ & $29.7 \pm 12.7^{\mathrm{a}}$ & $0.94 \pm 0.3$ & $1.12 \pm 0.25^{\mathrm{a}}$ \\
& $\mathrm{Ti}-5 \mathrm{Ag}-1 \mathrm{Fe}$ & $28.4 \pm 4.6$ & $34.4 \pm 12.1^{\mathrm{a}}$ & $0.95 \pm 0.1$ & $1.08 \pm 0.31$ \\
& $\mathrm{Ti}-5 \mathrm{Ag}-2.5 \mathrm{Fe}$ & $24.8 \pm 6.2$ & $28.5 \pm 3.5^{\mathrm{a}}$ & $0.93 \pm 0.1$ & $1.34 \pm 0.58^{\mathrm{a}}$ \\
& $\mathrm{Ti}-5 \mathrm{Ag}-5 \mathrm{Fe}$ & $34.8 \pm 3.3$ & $28.1 \pm 11.0$ & $0.94 \pm 0.1$ & $0.98 \pm 0.23$ \\
\hline
\end{tabular}

Data are expressed as mean values \pm standard deviation.

a Indicates $p<0.05$ when compared with $\mathrm{CP} \mathrm{Ti}$. 

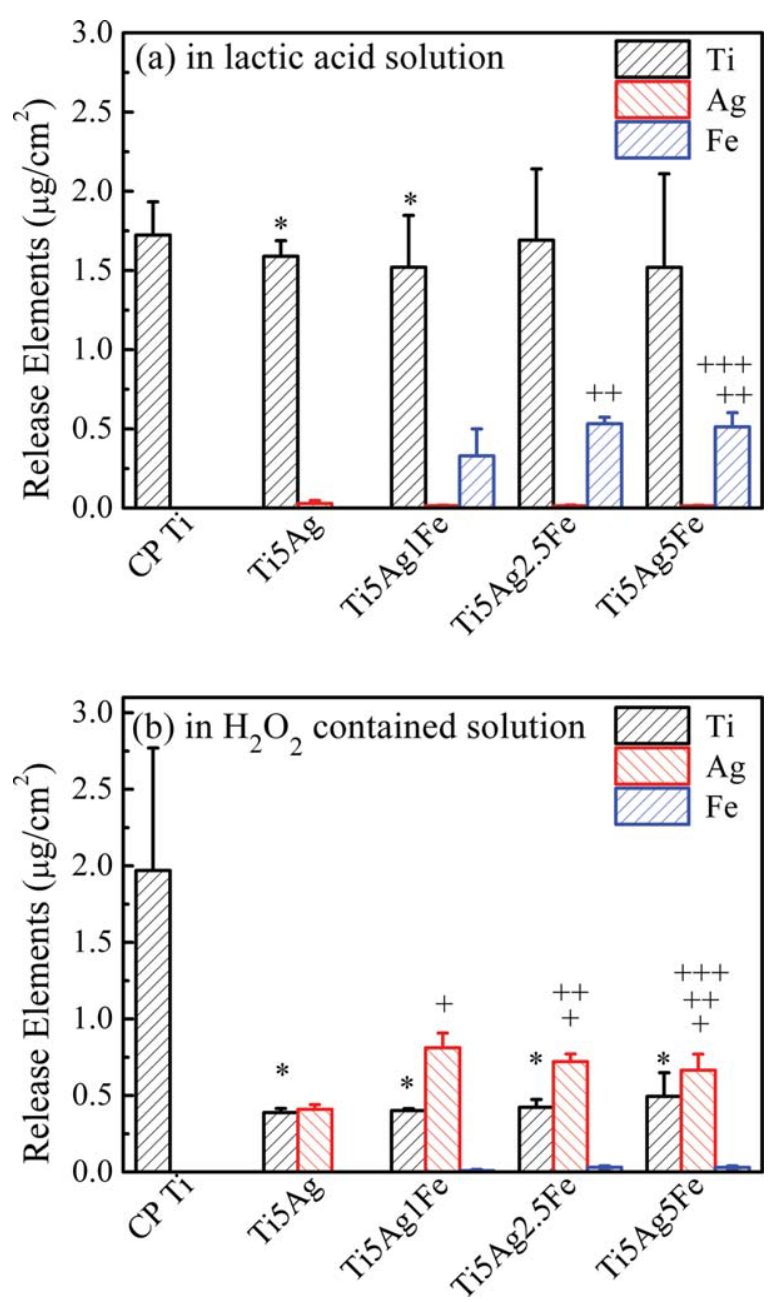

FIGURE 12. Total amount of dissolved elements ( $\mathrm{Ti}, \mathrm{Ag}$, and $\mathrm{Fe}$ ) released from $\mathrm{CP} \mathrm{Ti}$ and $\mathrm{Ti}-5 \mathrm{Ag}-\mathrm{xFe}$ alloys in $1 \%$ lactic acid solution (a) and $\mathrm{H}_{2} \mathrm{O}_{2}$ solution (b). * indicates $p<0.05$ when comparing with $\mathrm{CP}$ Ti group. + indicates $p<0.05$ when comparing with Ti-5Ag group, ++ indicates $p<0.05$ when comparing with Ti-5Ag-1Fe group, +++ indicates $p<0.05$ when comparing with Ti-5Ag-2.5Fe group. [Color figure can be viewed in the online issue, which is available at wileyonlinelibrary.com.]

Figure 15 shows the varying tendency of microhardness along with the increasing of alloying elements content for some newly developed cast titanium alloy. 5,6,12,13,48,49,51 Generally, all alloys exhibit an increase in microhardness with the addition of alloying elements. The Ti-5Ag-2.5Fe alloy has the largest microhardness values among all alloys except for Ti-10Cr alloy. Furthermore, the improved wear resistance could be attributed to their large hardness values. In many dental cases, plastic deformation and microscratch formation dominate the wear process. A positive correlation between hardness and wear resistance of a material in such cases has been reported. ${ }^{52}$ Moreover, Ti-5Ag-2.5Fe alloy has excellent hardness and wear resistance because of the combination of solid-solution strengthening by $\mathrm{Ag}$ and $\mathrm{Fe}$ and its $(\alpha+\beta)$ biphasic microstructure. Similar results have been recognized in dual phase alloys such as $(\alpha+\beta)$ titanium alloy, $(\alpha+\beta)$ brasses, and dual phase steels. It is widely accepted that the biphasic microstructure brings excellent strength without weakening too much plasticity. ${ }^{53}$

From the point of view of mechanical properties, Ti-5Ag$\mathrm{xFe}$ can be used for different dental devices. The microhardness of Ti-5Ag alloy is about $206 \mathrm{Hv}$, slightly higher than that of hardened type 3 dental casting gold alloys. ${ }^{44}$ Moreover, it is reported that the yield strength of the $\mathrm{Ti}-5 \% \mathrm{Ag}$ alloy is about $280 \mathrm{MPa}$ and corresponds to type 3 dental casting alloys. ${ }^{6}$ The Ti-5Ag alloy can be used for crowns and short-span bridges. The hardness of the Ti-5Ag-1Fe alloy is over $300 \mathrm{Hv}$, slightly higher than that of hardened type 4 dental casting gold alloys $(280 \mathrm{Hv}){ }^{50}$ This alloy can be applied to thin crowns and partial dentures. Moreover, large microhardness values and good wear resistance make Ti$5 \mathrm{Ag}-2.5 \mathrm{Fe}$ alloy suitable to replace $\mathrm{Co}-\mathrm{Cr}$ based alloys (microhardness about $320-520 \mathrm{Hv}^{30,54,55}$ ) and $\mathrm{Ni}-\mathrm{Cr}$ based alloys (microhardness about 350-430 $\mathrm{Hv}^{56}$ ). Ti-5Ag-5Fe alloy exhibits similar hardness and yield strength when compared with Ti-5Ag-1Fe alloy.
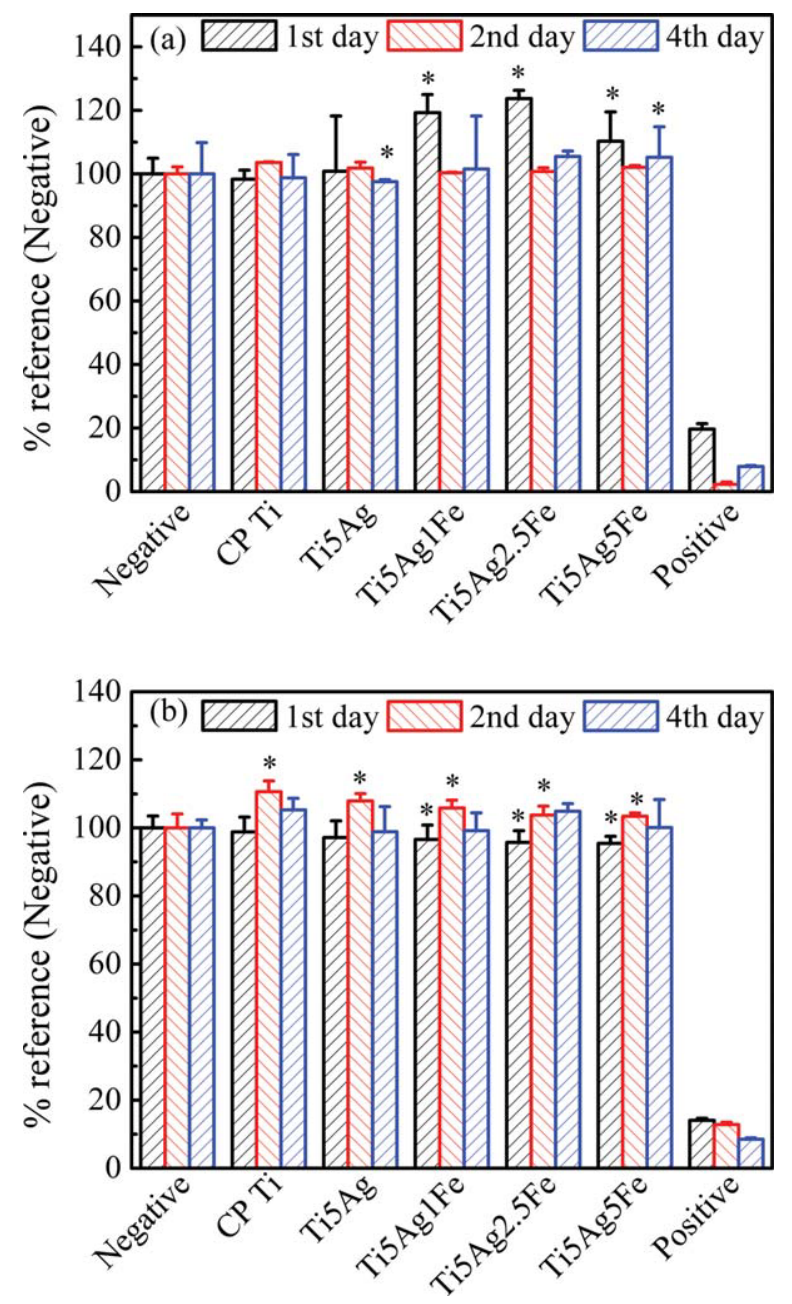

FIGURE 13. Cell viability expressed as a percentage of the viability of cells in the negative control after 1, 2, and 4 days of culture in $\mathrm{CP} \mathrm{Ti}$ and Ti-5Ag-xFe alloys extraction mediums: (a) L-929 cell line; (b) NIH3T3 cell line. * indicates $p<0.05$ when comparing with the negative group. [Color figure can be viewed in the online issue, which is available at wileyonlinelibrary.com.] 


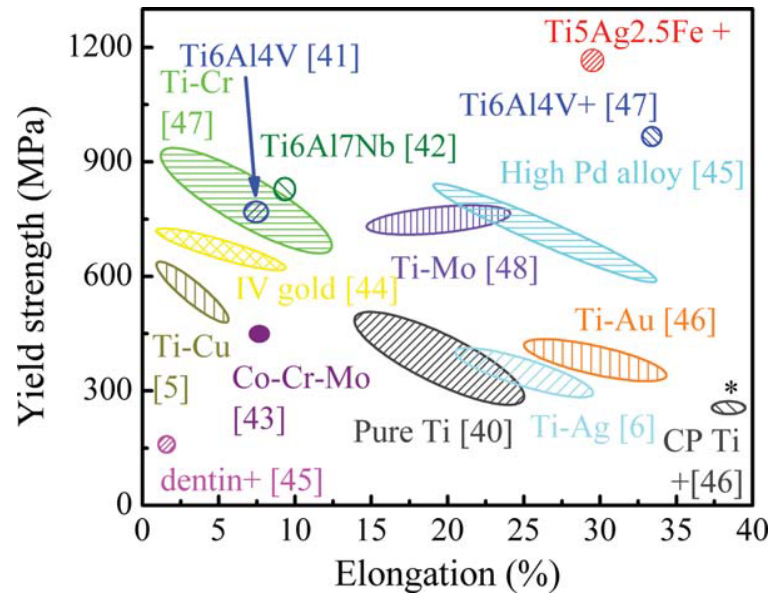

FIGURE 14. Comparison of yield strength and elongation of Ti-5Ag$2.5 \mathrm{Fe}$ alloy with some clinically used dental alloys and some newlydeveloped as-cast titanium alloys. + represents compressive yield strength; * represents elongation more than $40 \%$. [Color figure can be viewed in the online issue, which is available at wileyonlinelibrary. com.]

\section{Corrosion resistance}

Figure 16 compares the electrochemical parameters of some newly developed cast titanium binary alloys recommended by other researchers. ${ }^{9,57-59}$ The corrosion resistance of titanium alloy is greatly dependent on the corrosion environment, alloying elements, and their oxides formed. According to the reference, the addition of $\mathrm{Cu}$ an $\mathrm{Au}^{57,59}$ slightly deteriorate the corrosion resistance of titanium due to the precipitation of intermetallic compounds. On the contrary, the corrosion resistance of titanium could be improved by adding $\mathrm{Cr}$ and $\mathrm{Ag} .{ }^{9,58}$

Compared to $\mathrm{CP} \mathrm{Ti}$, higher corrosion potentials and similar passive current densities could be obtained for Ti-5Ag$\mathrm{xFe}$ alloys. In EIS tests, good agreement between the experimental data and fitted data is obtained, and the fitted parameters are shown in Table I. Large values of $R_{1}$ (of the

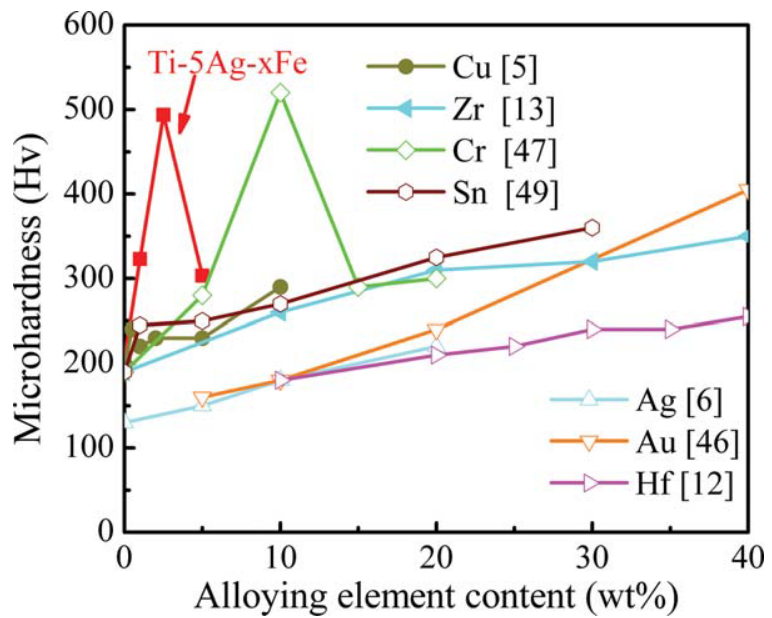

FIGURE 15. Varying tendencies of microhardness with the increase of alloying element content for some as-cast binary titanium alloy systems. [Color figure can be viewed in the online issue, which is available at wileyonlinelibrary.com.]

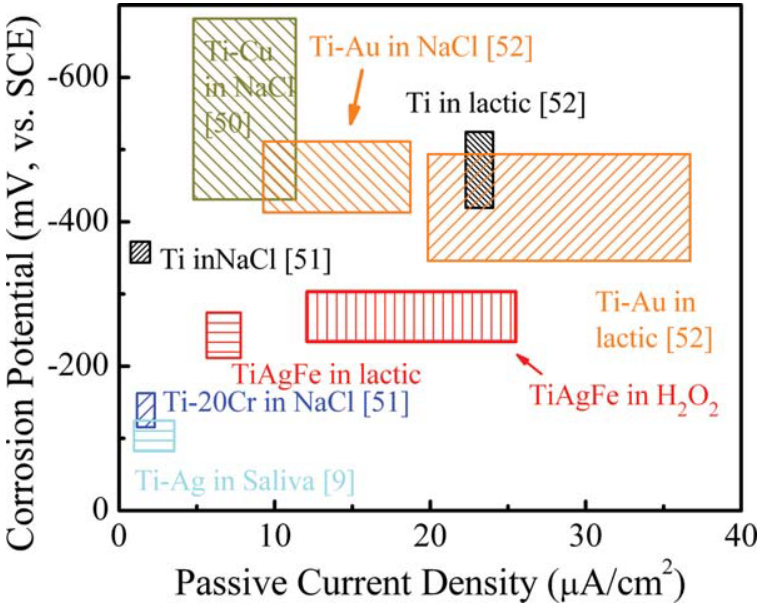

FIGURE 16. Comparison of the electrochemical parameters of Ti-5Ag$x F e$ alloys with other previously reported cast titanium alloys. [Color figure can be viewed in the online issue, which is available at wileyonlinelibrary.com.]

order of $1 \times 10^{5} \Omega \mathrm{cm}^{2}$ ) are obtained, confirming the formation of a passive film of $\mathrm{CP} \mathrm{Ti}$ and $\mathrm{Ti}-5 \mathrm{Ag}$-xFe alloys. In both lactic acid solution and $\mathrm{H}_{2} \mathrm{O}_{2}$-contained solution, it is interesting that $\mathrm{Ti}-5 \mathrm{Ag}$ and $\mathrm{Ti}-5 \mathrm{Ag}-2.5 \mathrm{Fe}$ alloy show significant higher impedances than that of CP Ti $(p<0.05)$. Large impedance can be associated with an increase of the passive layer thickness. ${ }^{60-62}$

The comparative study on the corrosion behavior of Ti$5 \mathrm{Ag}-\mathrm{xFe}$ alloys and CP Ti showed that Ti-5Ag-xFe alloys possess similar or better corrosion resistance than $\mathrm{CP} \mathrm{Ti}$, possibly attributed to the addition of Ag. ${ }^{9,10,63}$ However, the addition of Fe slightly decreased the corrosion resistance. In general, Ti-5Ag alloy, Ti-5Ag-1Fe alloy, and Ti-5Ag-2.5Fe alloy exhibit better corrosion resistance when compared to CP Ti. Moreover, fretting corrosion is very common in all load bearing metallic dental implants. ${ }^{64,65}$ The generation of ionic and particulate debris through fracture and abrasion of the metal oxide protective layers and their deposition in the local tissue has caused clinical concern. ${ }^{32}$ The combination of superior corrosion resistance and enhanced wear resistance makes Ti-5Ag-1Fe alloy and Ti-5Ag-2.5Fe alloy more suitable for dental applications.

\section{Biocompatibililty}

The in vitro cytotoxicity results indicate that $\mathrm{Ti}-5 \mathrm{Ag}-\mathrm{xFe}$ alloys do not present any cytotoxic effect and exhibited excellent biocompatibility. The superior cytocompatibility Ti$5 \mathrm{Ag}$-xFe alloys can be attributed to the low-ion release amount and the nontoxic alloying elements. Metal ions released from corrodible alloys to the surrounding tissues may cause biological responses in short term or prolonged periods. ${ }^{39}$

Titanium was widely accepted as nontoxic element, Wataha et al. $^{66}$ reported that the toxicity $50 \%$ (TC 50) of $\mathrm{Ti}^{4+}$ ions was about 13.44 and $50.4 \mathrm{mg} / \mathrm{L}$ for $\mathrm{L} 929$ cell lines and Balb/c3T3 cell lines, respectively. Similarly, the half maximal inhibitory concentration $\left(\mathrm{IC}_{50} \mathrm{~s}\right)$ of $\mathrm{Ti}^{4+}$ ions ${ }^{67}$ 
for L929 cell lines and M3T3-E1 cell lines was reported to be $52.32 \mathrm{mg} / \mathrm{L}$ and $41.76 \mathrm{mg} / \mathrm{L}$, respectively.

It is reported ${ }^{68}$ that silver nitrate solution with the concentration lower than $3.7 \times 10^{-4} \%$ has no effect on fibroblast culture in both optimal fibroblast culture medium and keratinocyte culture medium. The Ag release of Ti-5Ag-xFe alloys in $\mathrm{H}_{2} \mathrm{O}_{2}$-contained solution is in the range of $0.5-1$ $\mu \mathrm{g} / \mathrm{cm}^{2}$. In comparison, after $168 \mathrm{~h}$ immersion, the $\mathrm{Ag}$ release amount of $\mathrm{Ag}_{62.5} \mathrm{Pd}_{22.5} \mathrm{Cu}_{10.6} \mathrm{Au}_{1.6} \mathrm{In}_{1.8}$ (wt \%) alloy ${ }^{69}$ in 0.85 wt $\% \mathrm{NaCl}+3$ wt \% bovine serum albumin solution was about $8 \mu \mathrm{g} / \mathrm{cm}^{2}$.

In addition, Fe is believed as nutrition for human body and could not cause toxic effect at low concentrations. As much as $40 \mathrm{mg} / \mathrm{kg}$ elemental iron may produce significant systemic toxicity. ${ }^{70}$ The $\mathrm{IC}_{50} \mathrm{~s}^{67}$ of bivalent and trivalent $\mathrm{Fe}$ salts for L929 and MC3T3-E1 cells varies between 303.5 $\mathrm{mg} / \mathrm{L}$ and $32.6 \mathrm{mg} / \mathrm{L}$, which are much higher than the $\mathrm{Fe}$ ion concentrations released into the lactic acid solution or $\mathrm{H}_{2} \mathrm{O}_{2}$-contained solution.

\section{CONCLUSIONS}

In this study, Ti-5Ag-xFe alloys are prepared and their microhardness, yield strength, and wear resistance increase with their iron content. When the Fe content is $5 \%$, the alloy turns brittle. Ti-5Ag-xFe alloys also exhibit similar or improved corrosion resistance compared to $\mathrm{CP} \mathrm{Ti}$. The excellent corrosion resistance and the low level of dissolution are mainly attributed to the $\mathrm{TiO}_{2}$ film on the surface. The cytocompatibility tests show that Ti-5Ag-xFe alloys indicate similar cell viability than that of $\mathrm{CP}$ Ti. Because of their superior mechanical properties, excellent corrosion resistance, low ion release rate, and good biocompatibility, Ti$5 \mathrm{Ag}-1 \mathrm{Fe}$ alloy and Ti-5Ag-2.5Fe alloy may be good candidate as dental materials and can be used for different dental devices.

\section{REFERENCES}

1. Brunette DM, Tengvall $P$, Textor M, Thomsen $P$. Titanium in Medicine. Berlin: Springer; 2001.

2. Niinomi M. Mechanical properties of biomedical titanium alloys. Mater Sci Eng A 1998;243:231-236.

3. Ohkubo C, Shimura I, Aoki T, Hanatani S, Hosoi T, Hattori M, Oda Y, Okabe T. Wear resistance of experimental Ti-Cu alloys. Biomaterials 2003;24:3377-3381

4. Ho WF, Chiang TY, Wu SC, Hsu HC. Mechanical properties and deformation behavior of cast binary Ti-Cr alloys. J Alloy Compd 2009:68:533-538.

5. Kikuchi M, Takada Y, Kiyosue S, Yoda M, Woldu M, Cai Z, Okuno O, Okabe T. Mechanical properties and microstructures of cast Ti-Cu alloys. Dent Mater 2003;19:174-181.

6. Takahashi M, Kikuchi M, Takada Y. Mechanical properties and microstructures of dental cast Ti-Ag and Ti-Cu alloys. Dent Mater J 2002;21:270-280.

7. Kikuchi M, Takahashi M, Okabe T, Okuno O. Grindability of dental cast Ti-Ag and Ti-Cu alloys. Dent Mater J 2003;22:191-205.

8. Oh KT, Shim HM, Kim KN. Properties of titanium-silver alloys for dental application. J Biomed Mater Res B: Appl Biomater 2005;74: 649-658.

9. Zhang BB, Zheng YF, Liu Y. Effect of Ag on the corrosion behavior of Ti-Ag alloys in artificial saliva solutions. Dent Mater 2009; 25:672-677.
10. Zhang BB, Wang BL, Li L, Zheng YF. Corrosion behavior of Ti-5Ag alloy with and without thermal oxidation in artificial saliva solution. Dent Mater 2011:27:214-220.

11. Cai Z, Koike M, Sato H, Brezner M, Guo Q, Komatsu M, Okuno O, Okabe T. Electrochemical characterization of cast $\mathrm{Ti}-\mathrm{Hf}$ binary alloys. Acta Biomater 2005;1:353-356.

12. Sato $H$, Kikuchi M, Komatsu M, Okuno O, Okabe T. Mechanical properties of cast Ti-Hf alloys. J Biomed Mater Res B Appl Biomater 2005;72:362-367.

13. Ho WF, Chen WK, Wu SC, Hsu HC. Structure, mechanical properties, and grindability of dental Ti-Zr alloys. J Mater Sci Mater Med 2008;19:3179-3186.

14. Koike M, Ohkubo $C$, Sato H, Fujii H, Okabe. T. Evaluation of cast Ti-Fe-O-N alloys for dental applications. Mater Sci Eng C 2005;25: 349-356.

15. Ho WF, Cheng $\mathrm{CH}$, Pan $\mathrm{CH}, \mathrm{Wu} \mathrm{SC}, \mathrm{Hsu}$ HC. Structure, mechanical properties and grindability of dental Ti-10Zr-X alloys. Mater Sci Eng C 2009;29:36-43.

16. Hsu HC, Pan $\mathrm{CH}, \mathrm{Wu}$ SC, Ho WF. Structure and grindability of cast Ti-5Cr-xFe alloys. J Alloy Compd 2009;474:578-583.

17. Bordji K, Jouzeau JY, Mainard D, Payan E, Netter P, Rie KT, Stucky T, Hage-Ali M. Cytocompatibility of Ti-6Al-4V and Ti-5Al$2.5 \mathrm{Fe}$ alloys according to three surface treatments, using human fibroblasts and osteoblasts. Biomaterials 1996;17:929-940.

18. Miura I, Takaai T. Studies on some mechanical properties of titanium-silver-iron alloys. J Jpn Inst Metals 1960;24:5-8.

19. ASTM-F0067-00: Specification for unalloyed titanium, for surgical implant applications, Annual book of ASTM standards. Philadelphia, PA, USA: American Society for Testing and Materials; 2004.

20. Himmlová L, Dostálová T, Kácovský A, Konvicková S. Influence of implant length and diameter on stress distribution: A finite element analysis. J Prosthet Dent 2004;91:20-25.

21. Li SJ, Yang R, Li S, Hao YL, Cui YY, Niinomi M, Guo ZX. Wear characteristics of $\mathrm{Ti}-\mathrm{Nb}-\mathrm{Ta}-\mathrm{Zr}$ and $\mathrm{Ti}-6 \mathrm{Al}-4 \mathrm{~V}$ alloys for biomedical applications. Wear 2004;257:869-876.

22. Watts JF, Wolstenholme J. An Introduction to Surface Analysis by XPS and AES. Chichester: Wiley; 2003.

23. Carter WJ, Dunn JK, Fosdick LS, Moore BW. The formation of lactic acid in dental plaques. I. Caries-active individuals. J Dent Res 1956;35:778-785.

24. Al-Mobarak NA, Al-Mayouf AM, Al-Swayih AA. The effect of hydrogen peroxide on the electrochemical behavior of $\mathrm{Ti}$ and some of its alloys for dental applications. Mater Chem Phys 2006;99:333-340.

25. Shukla AK, Balasubramaniam R. Effect of surface treatment on electrochemical behavior of $\mathrm{CP} \mathrm{Ti}, \mathrm{Ti}-6 \mathrm{Al}-4 \mathrm{~V}$ and $\mathrm{Ti}-13 \mathrm{Nb}-13 \mathrm{Zr}$ alloys in simulated human body fluid. Corros Sci 2006;48:1696-1720.

26. Okazaki $Y$, Gotoh $E$. Comparison of metal release from various metallic biomaterials in vitro. Biomaterials 2005;26:11-21.

27. Noguchi T, Takemoto S, Hattori M, Yoshinari M, Kawada E, Oda $Y$. Discoloration and dissolution of titanium and titanium alloys with immersion in peroxide- or fluoride-containing solutions. Dent Mater J 2008;27:117-123.

28. Dobromyslov AV, Elkin VA. Martensitic transformation and metastable $\beta$-phase in binary titanium alloys with d-metals of 4-6 periods. Scripta Mater 2001;44:905-910.

29. Hsu HC, Wu SC, Chiang TY, Ho WF. Structure and grindability of dental Ti-Cr alloys. J Alloy Compd 2009;476:817-825.

30. Aoki T, Okafor ICl, Watanabe I, Hattori M, Oda Y, Okabe T. Mechanical properties of cast Ti-6Al-4V-XCu alloys. J Oral Rehab 2004;31:1109-1114.

31. Shahdad SA, McCabe JF, Bull S, Rusby S, Wassell RW. Hardness measured with traditional Vickers and Martens hardness methods. Dent Mater 2007;23:1079-1085.

32. Geetha M, Singh AK, Asokamani R, Gogia AK. Ti based biomaterials, the ultimate choice for orthopaedicimplants-A review. Prog Mater Sci 2009;54:397-425.

33. lijima D, Yoneyama $T$, Doi $H$, Hamanaka $H$, Kurosaki N. Wear properties of $\mathrm{Ti}$ and $\mathrm{Ti}-6 \mathrm{Al}-7 \mathrm{Nb}$ castings for dental prostheses. Biomaterials 2003;24:1519-1524.

34. Kang DK, Moon SK, Oh KT, Choi GS, Kim KN. Properties of experimental titanium-silver-copper alloys for dental applications. J Biomed Mater Res B Appl Biomater 2009;90:446-451.

35. Liu L, Qiu CL, Chen Q, Zhang SM. Corrosion behavior of Zr-based bulkmetallic glass in artificial body fluids. J Alloys Compd 2006;425:268-273. 
36. Assisa SL, Wolynecb S, Costa I. Corrosion characterization of titanium alloys by electrochemical techniques. Electrochim Acta 2006; 51:1815-1819.

37. Tamilselvi A, Raman V, Rajendran N. Corrosion behaviour of Ti$6 \mathrm{Al}-7 \mathrm{Nb}$ and Ti-6Al-4V ELI alloys in the simulated body fluid solution by electrochemical impedance spectroscopy. Electrochim Acta 2006;52:839-846.

38. González JEG, Mirza-Rosca JC. Study of the corrosion behavior of titanium and some of its alloys for biomedical and dental implant applications. J Electroanal Chem 1999;471:109-115.

39. Wahata JC. Biocompatibility of dental casting alloys: A review. J Prosthet Dent 2000;83:223-234.

40. ASTM-F0136-02A: Specification for wrought titanium-6aluminum4vanadium ELI (extra low interstitial) alloy for surgical implant applications, Annual book of ASTM standards. Philadelphia, PA USA: American Society for Testing and Materials; 2004.

41. ASTM-F1295-05: Specification for wrought titanium-6aluminum7niobium alloy for surgical implant applications, Annual book of ASTM standards. Philadelphia, PA, USA: American Society for Testing and Materials; 2004.

42. ASTM-F0075-01: Specification for cobalt-28 chromium-6 molybdenum alloy castings and casting alloy for surgical implants, Annual book of ASTM standards. Philadelphia, PA, USA: American Society for Testing and Materials; 2004.

43. Knosp H, Nawaz M, Stumke M. Dental gold alloys composition, properties and applications. Gold Bull 1981;14:57-64.

44. O'Brien WJ. Dental Materials and Their Selection, 3rd ed. Illinois: Quintessence; 2002.

45. Peyton FA, Mahler DB, Hershenov B. Physical properties of dentin. J Dent Res 1952;31:366-370.

46. Nemat-Nasser S, Guo WG, Cheng JY. Mechanical properties and deformation mechanisms of a commercially pure titanium. Acta Mater 1999;47:3705-3720.

47. Sun ZG, Hou HL, Zhou WL, Wang YQ, Li ZQ. The effect of hydrogen on microstructures evolution and deformation behaviors of Ti-6Al-4V alloys. J Alloy Compd 2009;476:550-555.

48. Takahashi M, Kikuchi M, Okuno O. Mechanical properties and grindability of experimental Ti-Au alloys. Dent Mater J 2004;23: 203-210.

49. Hattori M, Takemoto S, Yoshinari M, Kawada E, Oda Y. Effect of chromium content on mechanical properties of casting $\mathrm{Ti}-\mathrm{Cr}$ alloys. Dent Mater J 2010;29:570-574.

50. Ho WF. A comparison of tensile properties and corrosion behavior of cast Ti-7.5Mo with c.p. Ti, Ti-15Mo and Ti-6Al-4V alloys. J Alloy Compd 2008;464:580-583.

51. Hsu HC, Lin HC, Wu SC, Hong YS, Ho WF. Microstructure and grindability of as-cast Ti-Sn alloys. J Mater Sci 2010;45:1830 1836.

52. Gapido CG, Kobayashi H, Miyakawa O, Kohno S. Fatigue resistance of cast occlusal rests using $\mathrm{Co}-\mathrm{Cr}$ and $\mathrm{Ag}-\mathrm{Pd}-\mathrm{Cu}-\mathrm{Au}$ alloys. J Prosthet Dent 2003;90:261-269.
53. Ankem S, Margolin H, Greene CA, Neuberger BW, Oberson PG. Mechanical properties of alloys consisting of two ductile phases. Prog Mater Sci 2006;51:632-709.

54. Matković T, Slokar L, Matković P. Structure and properties of biomedical Co-Cr-Ti alloys. J Alloy Compd 2006;407:294-298.

55. Kashani H, Laridjani MS, Amadeh A, Khodagholi M, Ahmadzadeh $\mathrm{S}$. The influence of volumetric dilution on the strain induced $\gamma \rightarrow$ $\varepsilon$ martensitic transformation in GTAW processed Co-Cr-Mo alloy. Mater Sci Eng A 2008;478:38-42.

56. Bauer JR, Loguercio AD, Reis A, Rodrigues Filho LE. Microhardness of $\mathrm{Ni}-\mathrm{Cr}$ alloys under different casting conditions. Braz Oral Res 2006;20:40-46.

57. Osorio WR, Cremasco A, Andrade PN, Garcia A, Caram R. Electrochemical behavior of centrifuged cast and heat treated $\mathrm{Ti}-\mathrm{Cu}$ alloys for medical applications. Electrochim Acta 2010;55:759-770.

58. Takemoto S, Hattori M, Yoshinari M, Kawada E, Asami K, Oda Y. Corrosion behavior and surface characterization of $\mathrm{Ti}-20 \mathrm{Cr}$ alloy in a solution containing fluoride. Dent Mater J 2004;23:379-386.

59. Takahashi M, Kikuchi M, Takada Y, Okuno O, Okabe T. Corrosion behavior and microstructures of experimental Ti-Au alloys. Dent Mater J 2004;23:109-116.

60. Wang BL, Zheng YF, Zhao LC. Electrochemical corrosion behavior of biomedical $\mathrm{Ti}-22 \mathrm{Nb}$ and $\mathrm{Ti}-22 \mathrm{Nb}-6 \mathrm{Zr}$ alloys in saline medium. Mater Corros 2009;60:788-794.

61. Figueira N, Silva TM, Carmezima MJ, Fernandes JCS. Corrosion behaviour of NiTi alloy. Electrochim Acta 2009;54:921-926.

62. Souza MEP, Ballester M, Freire CMA. EIS characterisation of Ti anodic oxide porous films formed using modulated potential. Surf Coat Technol 2007;201:7775-7780.

63. Hong SB, Eliaz N, Sachs EM, Allen SM, Latanision RM. Corrosion behavior of advanced titanium-based alloys made by threedimensional printing (3DP ${ }^{\mathrm{TM}}$ ) for biomedical applications. Corros Sci 2001;43:1781-1791.

64. Mathew MT, Pai PS, Pourzal R, Fischer A, Wimmer MA. Significance of tribocorrosion in biomedical applications overview and current status. Adv Tribol 2009;2009:1-13.

65. Adya N, Alam M, Ravindranath T, Mubeen A, Saluja B. Corrosion in titanium dental implants: Literature review. J Indian Prosthodont Soc 2005:5:126-131.

66. John C, Wataha JC, Hanks CT, Sun Z. Effect of cell line on in vitro metal ion cytotoxicity. Dent Mater 1994;10:156-161.

67. Yamamoto A, Honma R, Sumita M. Cytotoxicity evaluation of 43 metal salts using murine fibroblasts and osteoblastic cells. J Biomed Mater Res 1998;39:331-340.

68. Poon VKM, Burd A. In vitro cytotoxity of silver: Implication for clinical wound care. Burns 2004;30:140-147.

69. Wataha JC, Nelson SK, Lockwood PE. Elemental release from dental casting alloys into biological media with and without protein. Dent Mater 2001;17:409-414.

70. Nordberg GF, Friberg L, Vouk VB. Handbook on the Toxicology of Metals Elsevier; 2007; 577 p. 